\title{
Pelatihan Microsoft Word Untuk Perangkat Desa Gelang Kecamatan Sumber Baru Kabupaten Jember
}

\author{
Ginanjar Abdurrahman \\ Jurusan Teknik Informatika, Universitas Muhammadiyah Jember \\ abdurrahmanginanjar@unmuhjember.ac.id
}

\begin{abstract}
In community service, especially village administration, ideally, village officials have essential Microsoft word competencies. However, from the report from the village apparatus of Gelang, only one person who mastered the basic Microsoft word was not comprehensive. Basic Microsoft word skills are considered necessary by the village apparatus of Gelang. This material chose because this material has not been mastered and deemed to be most often needed to handle the Gelang village office's administration, so it is necessary to hold basic Microsoft word training activities for the village apparatus of Gelang. This activity was born on September 7, 2016, introducing the presenter followed by a pre-test to determine the participants' initial abilities. After that, the presentation of material about basic Microsoft word accompanied by mentoring, practice, discussion and ended with a post-test continued with the material's production. The activity evaluation data shows that the participant's post-test scores' lowest score wa perfect compared to the participant's pre-test scores. The lowest score for the participant's post-test was 75, and the highest score for the participant was 90 compared to the pre-test score with the highest score only reaching 60/ Thus, it can say that there was a significant increase in the score.
\end{abstract}

Keywords: administration, village officials, competencies, evaluation, participant

\begin{abstract}
Abstrak
Dalam pelayanan masyarakat khususnya administrasi desa, idealnya perangkat desa mempunyai kompetensi Microsoft word dasar. Namun demikian dari laporan perangkat desa Gelang, perangkat desa yang menguasai Microsoft word dasar hanya satu orang dan itu pun tidak secara menyeluruh. Keterampilan Microsoft word dasar dianggap penting dimiliki oleh perangkat desa Gelang. Materi ini dipilih karena materi ini belum dikuasai dan dianggap paling sering dibutuhkan untuk menangani administrasi kantor desa Gelang, sehingga perlu diadakan kegiatan pelatihan Microsoft word dasar untuk perangkat desa Gelang. Kegiatan ini dilaksanakan pada tanggal 7 september 2016, diawali dengan perkenalan pemateri dilanjutkan dengan pretest untuk mengetahui kemampuan awal peserta. Setelah itu, dilanjutkan dengan pemaparan materi mengenai Microsoft word dasar disertai dengan pendampingan, praktek, diskusi, dan diakhiri dengan posttest. Dari data hasil evaluasi kegiatan dapat terlihat bahwa nilai posttest peserta sangat baik jika dibandingkan dengan nilai pretest peserta. Nilai terendah posttest peserta yakni 75 , dan nilai tertinggi peserta ada yang mencapai 90 sebanyak 1 orang dibandingkan dengan nilai pretest dengan nilai tertingginya hanya mencapai 60 . Dengan demikian dapat dikatakan bahwa terjadi peningkatan nilai yang cukup signifikan
\end{abstract}

Kata Kunci: administrasi, perangkat desa, kompetensi, evaluasi, peserta

\section{PENDAhuluan}

Desa Gelang merupakan desa di wilayah barat kabupaten Jember dan berbatasan dengan kabupaten
Lumajang. Desa Gelang termasuk dalam wilayah kecamatan Sumber Baru yang berjarak $57 \mathrm{~km}$ dari pusat kota. Luas wilayah desa Gelang adalah $\pm 5.574,603$ Ha dengan mayoritas masyarakat beretnis Madura. Wilayah desa Gelang dibagi 
menjadi empat dusun yakni Krajan, Paci, Tampingan, dan Lanasan. Dusun-dusun di desa Gelang memiliki letak geografis yang memutar seperti karet Gelang, sehingga wilayah ini dinamakan Desa Gelang (pemkabjember, 2013). Adapun batasbatas wilayah Desa Gelang adalah: (1) Bagian utara berbatasan dengan desa Andung Biru Kecamatan Tiris, kabupaten Probolinggo, (2) Bagian timur berbatasan dengan desa Karangbayat, kecamatan Sumberbaru, kabupaten Jember, (3) Bagian selatan berbataasan dengan desa Karangbayat dan Yosorati, kecamatan Sumberbaru, kabupaten Jember, (4) Bagian barat berbatasan dengan desa Jatiroto, kecamatan Sumberbaru, kabupaten Jember (Bappeda Jatim, 2013).

Mata pencaharian penduduk Desa Gelang sebagian besar di sektor pertanian dan perkebunan. Hasil utama pertanian desa Gelang adalah padi, sedangkan hasil utama perkebunan adalah tebu. Adapun sisa lahan di desa Gelang dimanfaatkan oleh penduduk untuk rumah dan untuk menanam tanaman penghasil kayu, salah satunya adalah Sengon. Selain itu, sebagian lahan lainnya dimiliki oleh PT. Perkebunan Nusantara (PTPN). Lahan milik PTPN ini ditanami dengan pohon Karet. Adapun mata pencaharian lainnya antara lain adalah pedagang, pegawai negeri, tukang cukur, tukang listrik, servis alat elektronik, mekanik, tukang kayu atau mebel, dan penjahit (Widiyanto, R, 2016).

Pendidikan di desa Gelang merupakan unsur yang diperhatikan oleh masyarakat. Hal ini dapat dilihat dari tingkat pendidikan yang dimiliki oleh penduduk sudah sampai tingkat perguruan tinggi. Di desa ini juga sudah ditemukan beberapa sekolah dasar (SD) dan sekolah menengah pertama (SMP). Sedangkan penduduk dengan tingkat pendidikan sekolah menengah atas (SMA) dan Perguruan Tinggi memilih untuk melanjutkan pendidikannya di luar Desa Gelang, karena memang belum ada SMA dan Perguruan Tinggi di Desa ini. Dengan tingkat pendidikan yang dimiliki tersebut, diharapkan penduduk usia produktif di desa Gelang memiliki pengetahuan dan keterampilan untuk menunjang pekerjaannya (Jemberkab, 2013)

Secara administratif, desa Gelang dipimpin oleh Kepala Desa yang memimpin 12 orang kepala bagian, yang terdiri dari 1 sekretaris, 7 Kepala urusan, dan 4 Kepala dusun (Kemenpan, 2013). Masing-masing kepala bagian tersebut dibantu perangkat desa lainnya untuk melaksanakan tugas dalam pelayanan masyarakat. Dalam pelayanan masyarakat, khususnya administrasi desa, idealnya perangkat desa mempunyai kompentensi Microsoft word dasar. Namun demikian, dari informasi salah satu perangkat desa, perangkat desa yang menguasai Microsoft word dasar hanya satu orang saja dan itu pun tidak secara menyeluruh, sehingga banyak pekerjaan administratif yang terhambat, dan menumpuk. Materi Microsoft word dasar dipilih karena materi ini belum dikuasai dengan baik dan dianggap yang paling sering digunakan untuk menangani administrasi kantor desa Gelang. Untuk itulah perlu diadakan kegiatan "Pelatihan Microsoft Word Dasar untuk Perangkat Desa Gelang Kecamatan Sumber Baru Kabupaten Jember”.

\section{METODE}

Adapun metode yang digunakan dalam kegiatan pengabdian masyarakat ini sebagai berikut :

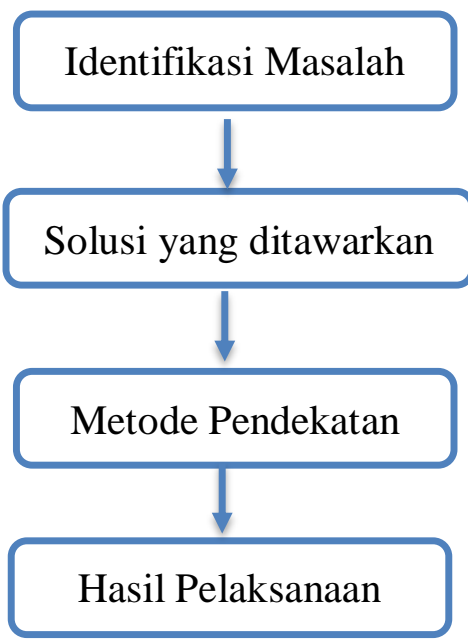

Gambar 1. Metode Penelitian

\section{Identifikasi Masalah}

Berdasarkan uraian di atas, maka dapat dirumuskan dua permasalahan utama yang terjadi pada perangkat Desa Gelang, yaitu:

1. Perangkat desa yang menguasai Microsoft word dasar hanya satu orang saja dan itu pun tidak secara menyeluruh, sehingga banyak pekerjaan administratif yang terhambat, dan menumpuk

2. Materi Microsoft word dasar diperlukan karena paling sering digunakan untuk kepentingan administrasi perangkat desa

Berdasarkan temuan tersebut, permasalahan yang dapat dirumuskan pada kegiatan Pengabdian Kepada Masyarakat ini adalah bagaimana meningkatkan pemahaman mengenai materi Microsoft word dasar perangkat desa Gelang, sehingga administrasi di Desa Gelang bisa dilaksanakan dengan efektif dan efisien? 


\section{Solusi yang Ditawarkan}

Untuk mengatasi permasalahan yang diuraikan pada rumusan masalah, diperlukan adanya solusi nyata yaitu dengan mengadakan pelatihan Mictosoft word dasar.

\section{Metode Pendekatan}

Kegiatan ini dilaksanakan selama satu hari yakni pada tanggal 7 september 2016 bertempat di Balai Desa Gelang. Kegiatan diawali dengan perkenalan pemateri dan ramah tamah, dilanjutkan dengan pengerjaan soal pretest oleh peserta untuk mengetahui kemampuan awal peserta. Setelah soal preteset dikerjakan, dilanjutkan dengan pemaparan materi disertai praktek langsung mengenai dasar-dasar Microsoft word yang berkaitan dengan administrasi. Setelah pemaparan materi dan diskusi serta praktek langusng, pemateri memberikan evaluasi berupa posttest untuk mengukut tingkat pemahaman peserta kegiatan setelah diberikan materi. Sebagai gambaran secara umum kegiatan dirangkum dalam Tabel 1 berikut ini.

Tabel 1. Gambaran Umum Kegiatan

\begin{tabular}{|c|c|c|c|}
\hline No. & $\begin{array}{l}\text { Materi } \\
\text { Pengabdian }\end{array}$ & Kegiatan & Target \\
\hline 1. & Pretest & $\begin{array}{l}\text { Peserta } \\
\text { mengerjakan } \\
\text { sosl pretest } \\
\text { selama } 10 \\
\text { menit }\end{array}$ & $\begin{array}{l}\text { Pretest } \\
\text { dilaksanakan } \\
\text { untuk mengukur } \\
\text { pemahaman } \\
\text { awal Perangkat } \\
\text { Desa Gelang } \\
\text { mengenai materi } \\
\text { Microsoft word } \\
\text { dasar. }\end{array}$ \\
\hline 2 & $\begin{array}{l}\text { Pemaparan } \\
\text { Materi } \\
\text { - Membuka } \\
\text { aplikasi } \\
\text { Microsoft } \\
\text { Word } \\
\text { - Mengatur } \\
\text { jenis kertas } \\
\text { - Mengatur } \\
\text { margin } \\
\text { - Mengatur } \\
\text { Posisi kertas } \\
\text { - Mengatur } \\
\text { Huruf }\end{array}$ & $\begin{array}{l}\text { Pemaparan } \\
\text { Materi } \\
\text { Diskusi dan } \\
\text { Praktek } \\
\text { Microsoft } \\
\text { word dasar }\end{array}$ & $\begin{array}{l}\text { Perangkat desa } \\
\text { memiliki } \\
\text { pengetahuan } \\
\text { dasar-dasar } \\
\text { Microsoft word } \\
\text { dan dapat } \\
\text { mempraktekan } \\
\text { untuk membantu } \\
\text { pekerjaan yang } \\
\text { berkaitan } \\
\text { dengan } \\
\text { administrasi } \\
\text { desa Gelang. }\end{array}$ \\
\hline
\end{tabular}

\begin{tabular}{|c|c|c|c|}
\hline No. & $\begin{array}{l}\text { Materi } \\
\text { Pengabdian }\end{array}$ & Kegiatan & Target \\
\hline & 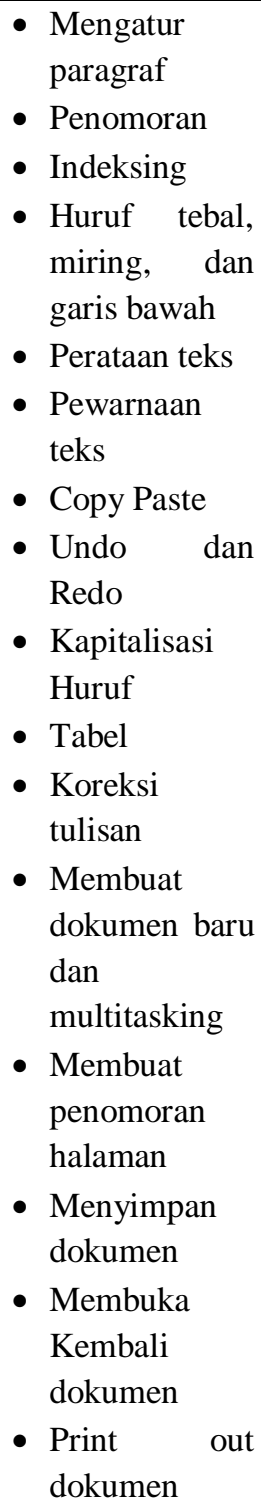 & & \\
\hline 3. & Posttest & $\begin{array}{l}\text { Peserta } \\
\text { mengerjakan } \\
\text { sosl posttest } \\
\text { selama } 10 \\
\text { menit }\end{array}$ & $\begin{array}{l}\text { Posttest } \\
\text { dilaksanakan } \\
\text { untuk mengukur } \\
\text { pemahaman } \\
\text { peserta setelah } \\
\text { mendapatkan } \\
\text { pemaparan dari } \\
\text { pelaksana } \\
\text { pengabdian. }\end{array}$ \\
\hline
\end{tabular}




\section{HASIL DAN PEMBAHASAN}

Hasil evaluasi peserta terkait pemahaman konsep disajikan dalam bentuk nilai dengan skala nilai antara (0-100) terhadap 20 peserta pelatihan. Penilaian dilaksanakan dalam dua tahap, yakni pretest (sebelum penyampaian materi) dan posttest (sesudah penyampaian materi). Hasil pretest disajikan dalam grafik sebagai berikut:

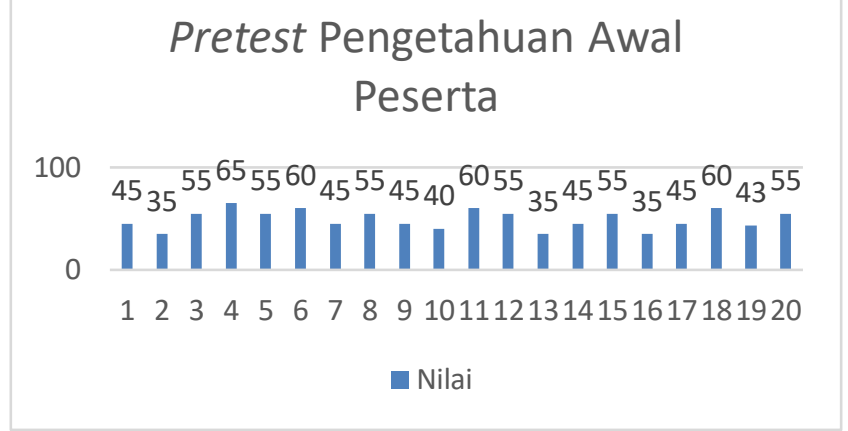

Gambar 2. Pretes Peserta

Sedangkan hasil posttest disajikan dengan grafik sebagai berikut:

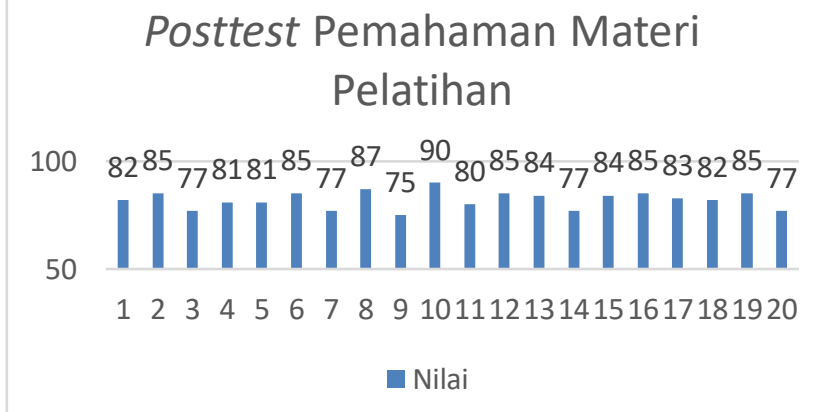

\section{Gambar 3. Post Test Peserta}

Dari data hasil evaluasi tersebut dapat terlihat bahwa pemahaman materi peserta setelah pemberian materi sudah sangat baik jika dibandingkan dengan sebelum pemaparan materi. Hal ini dapat dilihat dari nilai terendah posttest peserta yakni 75, dan nilai tertinggi peserta ada yang mencapai 90 sebanyak 1 orang. Jika dibandingkan dengan nilai pada pretest dengan nilai tertinggi hanya mencapai 60, dapat dikatakan bahwa terjadi peningkatan nilai yang cukup signifikan.

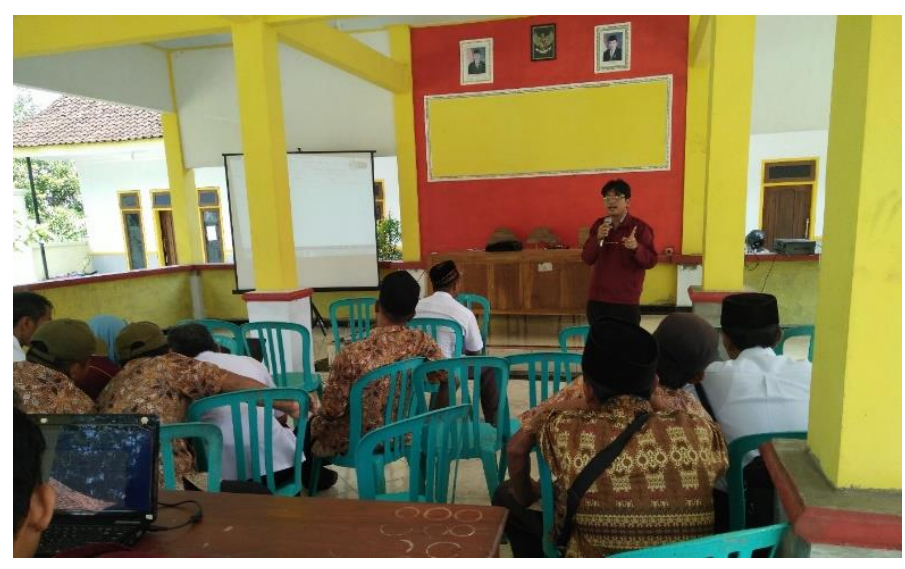

Gambar 4. Penyampaian Materi dan Diskusi

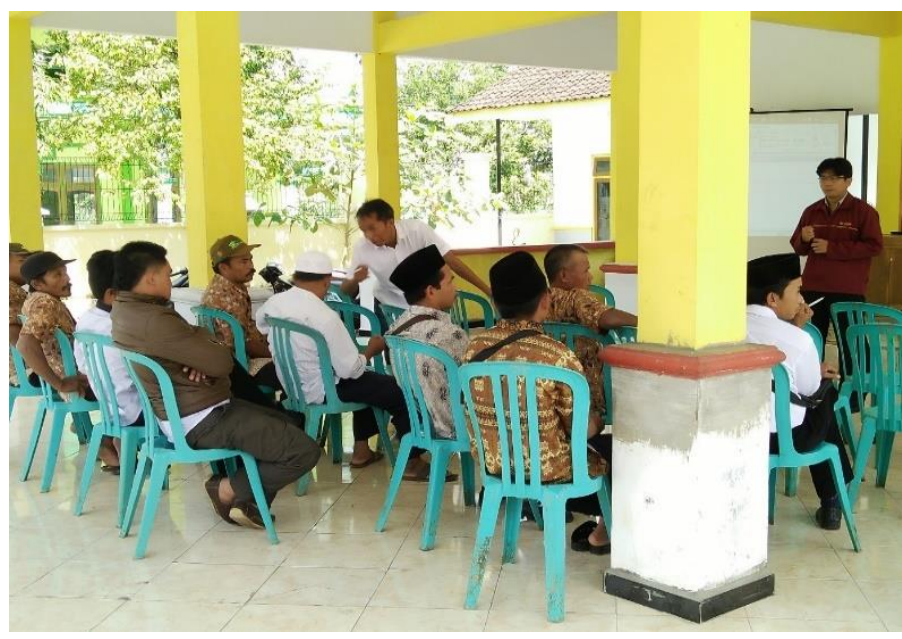

Gambar 5. Penyampaian Materi dan Diskusi

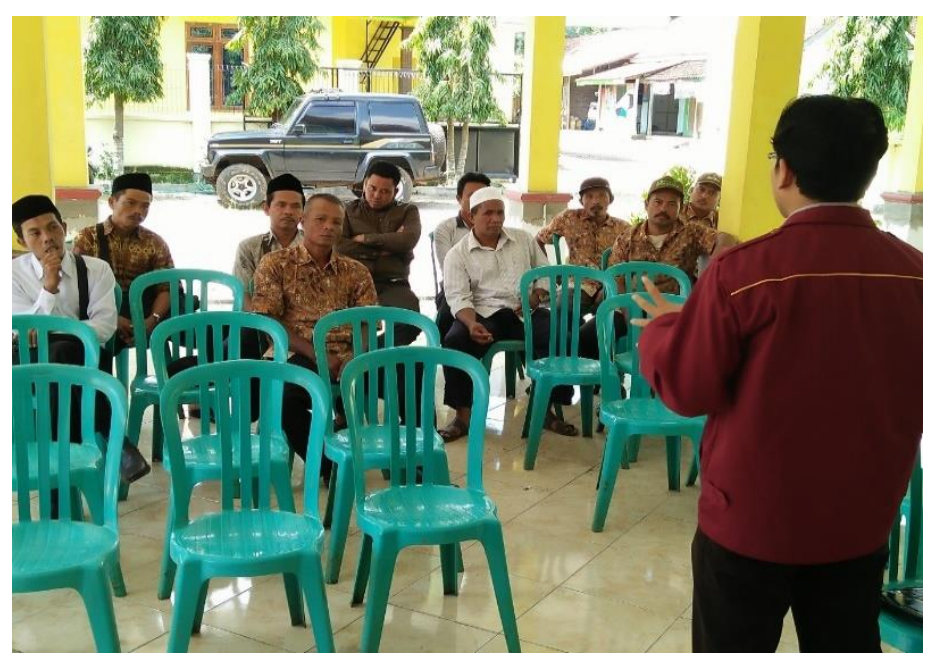

Gambar 6. Penyampaian Materi dan Diskusi 


\section{KESIMPULAN}

Kegiatan pengabdian kepada masyarakat ini berjalan dengan baik dengan ditandai antusiasme peserta selama kegiatan. Selain itu, ketercapaian tujuan kegiatan ini ditunjukkan dengan adana peningkatan pemahaman peserta yang dapat dilihat dari nilai evaluasi kegiatan. Dari data hasil evaluasi tersebut dapat terlihat bahwa pemahaman materi peserta setelah pemberian materi sudah sangat baik jika dibandingkan dengan sebelum pemaparan materi.

Hal ini dapat dilihat dari nilai terendah posttest peserta yakni 75, dan nilai tertinggi peserta ada yang mencapai 90 sebanyak 1 orang. Jika dibandingkan dengan nilai pada pretest dengan nilai tertinggi hanya mencapai 60, dapat dikatakan bahwa terjadi peningkatan nilai yang cukup signifikan

\section{UCAPAN TERIMAKASIH}

Penulis menyampaikan terima kasih kepada beberapa pihak yang telah mendukung dalam pelaksanaan kegiatan pengabdian kepada masyarakat ini, khususnya LPPM Universitas Muhammadiyah Jember karena telah memberikan dukungan dana pelaksanaan pengabdian.

\section{DAFTAR PUSTAKA}

Bappeda Jatim. (2013). Potensi Kabupaten Jember. http://bappeda.jatimprov.go.id/bappeda/wpcontent/uploads/potensi-kab-kota-2013/kab-jember-2013.pdf Jemberkab. (2013). Profil Kabupaten Jember. https://www.jemberkab.go.id/

Kemenpan. (2013). Kepala Administratif Desa Gelang. https://sipp.menpan.go.id/ pemkabjember. (2013). Profil Desa Gelang. http://www.pemkabjember.go.id/v3/kecamatan/sumberbaru.ph $\mathrm{p}$

Widiyanto, R, et al. (2016). Laporan Kuliah Kerja Nyata di Desa Gelang Kecamatan Sumberbaru Kabupaten Jember. 